\title{
Evaluasi Suplementasi Indigofera zollingeriana Sebagai Sumber Green Protein concentrate terhadap Produksi Gas Metan, Amonia dan Sintesis Protein Mikroba Rumen
}

\author{
Afzalani Afzalani*, R.A. Muthalib, Rahmi Dianita, \\ Fachroerrozi Hoesni, Raguati Raguati, Endri Musnandar \\ Fakultas Peternakan Universitas Jambi \\ *Corresponding email: afzalani@unja.ac.id
}

\begin{abstract}
Abstrak. Penggunaan sumber protein murah, berkualitas, menghasilkan emisi metan dan ammonia rendah merupakan persyaratan yang perlu dipertimbangkan dalam sistim produksi ternak ruminansia. Adanya pelarangan penggunaan sumber protein yang berasal dari tepung ikan oleh Europe Commission, mendorong upaya eksplorasi sumber protein yang berasal dari tanaman untuk dapat digunakan sebagai sumber protein konsentrat yang dikenal dengan green protein concentrate.Tanaman Indigofera zollingeriana adalah leguminosa yang potensial untuk digunakan sebagai sumber pakan yang memiliki kandungan protein tinggi yakni sekitar $25-27 \%$. Namun demikian, perlu dilakukan evaluasi mendalam terkait dengan sifat metabolismenya di rumen. Penelitian ini bertujuan untuk mengevaluasi tanaman Indigofera zollingeriana (IZ) sebagai sumber suplemen green protein concentrate terhadap produksi gas metan, ammonia dan sintesis protein mikroba. Penelitian ini dilaksanakan dalam Rancangan Acak Lengkap (RAL) terdiri dari 4 perlakuan dan 5 ulangan. Perlakuan suplementasi I. zollingeriana (IZ) sebagai sumber green protein concentrate disusun sebagai berikut : $\mathrm{R} 0=$ Pakan dasar $(60 \%$ hijauan dan $40 \%$ konsentrat $+0 \% \mathrm{IZ}, \mathrm{R} 1 ; \mathrm{R} 0+10 \% \mathrm{IZ}, \mathrm{R} 2$; R0 + 20\% IZ, dan R3; R0 + 30\% IZ. Hasil penelitian mununjukkan bahwa suplementasi IZ nyata $(\mathrm{P}<0.05)$ meningkatkan produksi gas total, ammonia $\left(\mathrm{N}-\mathrm{NH}_{3}\right)$, total volatile fatty acid (TVFA), metabolism energy (ME) serta berpengaruh nyata $(\mathrm{P}<0.05)$ menurunkan gas metan dan persentase gas metan. Sedangkan perlakuan R1 nyata $(\mathrm{P}<0.05)$ lebih tinggi dalam menghasilkan $\mathrm{KcBK}, \mathrm{KcBO}$, dan produksi protein mikroba (PPM). Dari hasil penelitian dapat disimpulkan bahwa sifat protein IZ memiliki ketahan yang rendah terhadap perombakan mikroba rumen, relatif rendah dalam menurunkan produksi gas metan. Suplementasi IZ sampai taraf 10\% (R1) menghasilkan KcBK, KcBO dan PPM lebih tinggi. Perlu upaya proteksi protein asal IZ guna menekan perombakannya oleh mikroba di rumen.
\end{abstract}

Kata kunci: Amonia; Gas metan; Indigofera zollingeriana; Protein mikroba; Suplementasi

Abstract. The use of protein with low-cost, high quality, low methane, and ammonia emissions are a prerequisite as a protein source in ruminant. However, the European Commission has prohibited protein derived from fish meals for ruminant feeds. So encouraging efforts to explore the other protein sources to be most important. Most of the high protein legumes grow in tropical areas such as Indonesia and have the potential as an alternative protein source in ruminant feed, including Indigofera zollingeriana (25-27\% protein content). But many browse legumes with high protein are a heterogeneous group of plants, with variable secondary metabolic content and rumen degradable protein. The aim of this experiment was to evaluate the characteristics fermentation of IZ as green protein supplement on in vitro methane, ammonia and microbial protein production. The experiment was a completely randomized design with four different level supplementation of Indigofera zollengeriana (IZ) as green protein concentrate and five replications. The treatment diets were R0; basal diet $(60 \%$ forage $+40 \%$ concentrate $)+0 \%$ $I Z, R 1 ; R 0+10 \% I Z, R 2 ; R 0+20 \% I Z$, and $R 3 ; R 0+30 \%$ IZ. The experiment result showed that supplemenatation of IZ was significant effects $(P<0.05)$ to increase total gas, ammonia $\left(\mathrm{N}-\mathrm{NH}_{3}\right)$, total volatile fatty acid $(T V F A)$, and metabolizable energy $(M E)$ and significant effect $(P<0.05)$ to decrease of methane and methane percentage. Supplementation IZ at a level of $10 \%$ was significantly higher for dry matter digestibility $(D M D)$, organic matter digestibility $(O M D)$, and microbial protein production $(P P M)$ than diets treatment of RO, R2, and R3. The experiment concluded that Supplementation of I. zollingeriana (IZ) was able to reduce the methane gas production. Protein characteristics of IZ have easily degradable by rumen microbe showed the ammonia production was linearly increasing by $45.66 \%$ for each increasing level of IZ supplementation. Microbial protein production was higher $(184.33 \mathrm{mg} / \mathrm{ml})$ obtained of IZ supplementation up to $10 \%(R 1)$. The experiment suggests doing protected protein of IZ when be used as a protein source in ruminant diets.

Keywords: Ammonia; Methane, Indigofera zollingeriana; Microbial protein; Supplementation

\section{PENDAHULUAN}

Ternak ruminansia memiliki kemampuan untuk mengkonversikan bahan pakan yang sedikit atau tidak bernilai sama sekali bagi manusia, menjadi bahan pangan yang berkualitas tinggi seperti daging dan susu untuk memenuhi kebutuhan nutrisi bagi manusia (Broderick, 2017). Komposisi asam amino esensial dari daging dan susu yang yang diproduksi dari ternak ruminansia, menjadikan sumber protein tersebut sebagai tambahan yang berharga untuk suplai pangan manusia. Diperkirakan akan ada peningkatan permintaan protein ruminansia di masa depan. Peningkatan kemampuan produktifitas per ekor ternak melalui penggunaan sumber protein murah dan berkualitas akan dapat 
menurunkan biaya serta gangguan lingkungan selama proses pemeliharaan ternak hingga berproduksi (daging atau susu).

Protein bahan pakan pada ternak ruminansia dikelompokkan dalam dua bagian yakni, protein yang didegradasi di rumen (rumen degradable protein $=\mathrm{RDP}$ ) dan protein yang tidak didegradasi di rumen (rumen undegradable protein $=\mathrm{RUP})$, dimana RDP terdiri dari nitrogen bukan protein (NPN) dan nitrogen protein. Ketika protein pakan perombakannya berlebihan, akibatnya efisiensi pemanfaatannya untuk produksi menurun tajam dan sejumlah besar hilang sebagai Nfeses, urin, dan gas $\mathrm{N}$ yang dapat menyebabkan efek negatif terhadap lingkungan. Disamping itu menyebabkan meningkatnya biaya dan efisiensi protein yang rendah (Bach dkk., 2005; Ružić-Muslić, 2014).

Pada saat ini Europe commission telah melarang penggunaan tepung ikan dalam makanan untuk ternak sebagai sumber protein, sehinga banyak penelitian telah difokuskan pada mempelajari efek dari penggunaan kedelai, bunga matahari dan sumber protein "unconventional" seperti sumber protein yang bersal dari tanaman pakan seperti legume pohon sebagai sumber green protein concentrate dalam makanan untuk nutrisi ruminansia. (Ružić-Muslić, 2014). Indigofera zollingeriana merupakan salah satu legum yang potensial untuk pakan ternak karena berkualitas tinggi dan toleran terhadap beragam kondisi lingkungan. Disamping itu tanaman ini memeiliki kandungan protein yang cukup tinggi yakni berkisar 25.17 - 26.44\% meskipun ditanam dengan kerapatan tanaman yang berbeda (Kumalasari dkk., 2017) . Produksi dan kualitas I. zollingeriana terlihat lebih tinggi dibandingkan legum lainnya, sehingga termasuk legum yang mempunyai prospek tinggi untuk dikembangkan sebagai komoditi industri konsentrat protein hijau (Abdullah, 2014). Tanaman ini juga adaftif dikembangkan di Indonesia karena sifatnya yang toleran terhadap musim kering, tahan genangan air serta tahan terhadap salinitas tanah. Selain itu tanaman ini memiliki pertumbuhan yang sangat cepat, adaptif terhadap tingkat kesuburan tanah rendah dan mudah dalam pemeliharaannya (Kumalasari dkk., 2017).

Penelitian ini berfokus pada evaluasi penggunaan I. zollingeriana sumber green protein concentrate untuk pakan ternak ruminansia.

\section{METODE}

\section{Persiapan Sampel dan Pakan Penelitian}

Sampel I. zollingeriana dan hijauan rumput kolonjono (Brachearia mutica) dipanen dari kebun percobaan Fakultas Peternakan Universitas Jambi. Sampel dikeringkan pada panas matahari, kemudian dilanjutkan pengeringan menggunakan oven suhu $60^{\circ} \mathrm{C}$ selama 24 jam dan digiling dengan ukuran saringan 1 $\mathrm{mm}$ sebelum digunakan dalam campuran pakan penelitian serta inkubasi in vitro.
Pakan penelitian yang digunakan sebagai pakan dasar disusun dengan rasio hijauan konsentrat 60:40\%, dengan kandungan protein $14 \%$ dan TDN $65 \%$. Konsentrat diformulasi menggunakan dedak 58\%, jagung giling $25 \%$, bungkil kedele $6 \%$, bungkil kelapa $9 \%$, mineral mix $1 \%$ dan garam $1 \%$. Hijauan yang digunakan yakni rumput kolonjono (Brachiaria mutica). Komposisi kimia hijauan, konsentrat, I. Zollingeriana dan ransum percobaan tercantum pada Tabel 1 dan Tabel 2.

Empat jenis pakan percobaan yang digunakan dalam penelitian terdari $\mathrm{R} 0=60 \%$ Hijauan $+40 \%$ konsentrat+ $0 \%$ I. zollingeriana (IZ), R1= R0 + $10 \% \mathrm{IZ}$, $\mathrm{R} 2=\mathrm{R} 0+20 \% \mathrm{IZ}$ dan $\mathrm{R} 3=\mathrm{R} 0+30 \% \mathrm{IZ}$.

\section{Prosedur Inkubasi In Vitro}

Cairan rumen diambil dari rumah potong hewan dari 2 ekor ternak sapi Bali jantan sebagai donor. Ternak sapi sebelum dipotong diberi pakan 2 kali sehari dengan pakan yang mengandung hijauan konsentrat 60:40\%, berlangsung selama 3 hari sebelum dipotong. Koleksi cairan rumen dilakukan berdasarkan prosedur Bioscreen Technologies (2015).

Cairan rumen dimasukkan ke dalam botol plastik dan di tempatkan dalam ice box yang berisi air hangat suhu $39-40^{\circ} \mathrm{C}$, dibawa kelaboratorium, disaring dengan menggunakan 4 lapis kain dan dicampur dengan buffer McDougall (1:4 v/v) sesuai prosedur Tilley dan Terry (1963).

Sebanyak $2000 \mathrm{ml}$ larutan campuran anatara cairan rumen dan McDougall dimasukkan ke dalam botol gelap kapasitas $2500 \mathrm{ml}$, dialiri dengan gas $\mathrm{CO}_{2}$ dan selanjutnya dipasang automatic dispenser pipette. Ditimbang sejumlah $500 \mathrm{mg}$ pakan penelitian, masukkan dalam botol serum kapasitas $100 \mathrm{ml}$, dimasukkan ke dalam oven suhu $39^{\circ} \mathrm{C}$ selama semalam, dan kemudian masukkan sebanyak $40 \mathrm{ml}$ larutan campuran cairan rumen-buffer, ditutup dengan karet penutup dan dijepit menggunakan alumunium seal cup.

Sebanyak 43 botol serum yang terdiri dari 4 perlakuan, 5 ulangan dan masing-masing berisi 2 unit penelitian serta 3 larutan blanko (cairan rumen-buffer) diinkubasikan dalam inkubator suhu $39^{\circ} \mathrm{C}$ selama 48 jam. Setiap botol serum diinjeksi dengan syringe melalui karet penutup untuk mengeluarkan gas sebagai titik awal dimulainya inkubasi.

Produksi gas diukur secara manual pada waktu inkubasi 3, 6, 9, 12, 24 dan 48 jam dengan menginjeksikan jarum menggunakan gelas syringe $10 \mathrm{ml}$ (Fortune $^{\circledR}$ ) dengan melihat pergerakan piston pada skala dari glass syringe dan dicatat sebagai produksi gas yang yang dihasilkan. Gas yang diperoleh selanjutnya digunakan untuk mengukur produksi gas metan.

Produksi gas metan diukur menggunakan metode yang dimodifikasi dari Fieves dkk. (2005). Syringe yang berisi gas dimasukkan melalui saluran in-let gas washing glass $\left(\right.$ Duran ${ }^{\mathrm{TM}}$ ) yang berisi larutan $\mathrm{NaOH} 4 \mathrm{M}$ guna 
menyerap $\mathrm{CO}_{2}$, dan pada saluran out-let dipasang dengan gelas syringe yang lain untuk mengukur gas metan. Total produksi gas (TG) dan gas metan dihitung setelah dikoreksi dengan balnko.

Konsentrasi metan $\left(\mathrm{CH}_{4}\right)$ dan potensi reduksinya gas metan (PRM) dihitung dengan menggunakan persamaan berikut :

$$
\begin{aligned}
& \mathrm{CH}_{4}(\%)=\frac{\text { Total } \mathrm{CH} 4(\mathrm{ml})}{\text { Total } \mathrm{Gas}(\mathrm{ml})} \times 100 \% \\
& \text { PRM }(\%)=\frac{\text { Total CH4 (kontrol)-Total CH4(IZ) }}{\text { Total CH4 (kontrol) }} \times 100 \%
\end{aligned}
$$

Kandungan energy metabolis (ME, MJ/kg DM) dihitung dengan menggunakan persamaan Menke and Steingass (1988), dan total volatile fatty acid (TVFA) menggunakan persamaan Getachew dkk. (2008) sebagai berikut;

$\mathrm{ME}(\mathrm{MJ} / \mathrm{kg} \mathrm{DM})=2.2+0.136 \times \mathrm{GP}_{24}+0.057 \mathrm{CP}+0.0029 \mathrm{CP} 2$

TVFA $\left(\mu \mathrm{mol} \mathrm{L} \mathrm{L}^{-1}\right)=0.0239 \mathrm{GP}_{24}-0.00425$

Dimana, CP dan GP adalah persentase protein kasar dan produksi gas pada 24 jam inkubasi. Sedangkan produksi protein mikroba dihitung berdasarkan Blummel dkk. (1997) yakni;

Produksi protein mikroba $(\mathrm{PPM})(\mathrm{mg} / \mathrm{g} \mathrm{BK})=\mathrm{mg}$ KcBK- (ml gas $/ 24$ jam x $2.2 \mathrm{mg} / \mathrm{ml})$, dimana $2.2 \mathrm{mg} / \mathrm{ml}$ adalah faktor stokiometri yang menggambarkan mg dari $\mathrm{C}, \mathrm{H}$ dan $\mathrm{O}$ yang dibutuhkan untuk memproduksi VFA yang dihubungkan dalam produksi $1 \mathrm{ml}$ gas.

Tabel 1. Komposisi kimia hijauan, konsentrat, I zolingeriana dan ransum dasar

\begin{tabular}{lcccc}
\hline Zat Makanan & Hijuan & Konsentrat & I.zolingeriana & Ransum Dasar \\
\hline Bahan Kering,\% & 91.96 & 91.48 & 93.53 & 91.93 \\
Protein Kasar, \% & 12.94 & 12.47 & 28.12 & 14.01 \\
Lemak Kasar,\% & 1.37 & 3.64 & 5.91 & 2.46 \\
Serat Kasar,\% & 27.67 & 8.81 & 9.11 & 20.15 \\
BETN, \% & 50.13 & 68.74 & 49.25 & 56.02 \\
Abu, \% & 7.89 & 6.34 & 7.61 & 7.37 \\
TDN, \% & 61.92 & 70.48 & 66.97 & 65.06 \\
\hline
\end{tabular}

Tabel 2. Komposisi kimia pakan penelitian

\begin{tabular}{lcccc}
\hline Zat Makanan & R0 & R1 & R2 & R3 \\
\hline Bahan Kering,\% & 91.93 & 91.98 & 92,8653 & 93.33 \\
Protein Kasar, \% & 14.01 & 16.82 & 19,634 & 22.45 \\
Lemak Kasar,\% & 2.46 & 3.05 & 3,642 & 4.23 \\
Serat Kasar,\% & 20.15 & 21.06 & 21,972 & 22.88 \\
BETN, \% & 56.02 & 60.95 & 65,87 & 70.80 \\
Abu, \% & 7.37 & 8.13 & 8,892 & 9.65 \\
TDN, \% & 65.06 & 71.76 & 78,454 & 85.15 \\
\hline
\end{tabular}

\section{Kecernaan Bahan Kering dan Bahan Organik}

Pada akhir inkubasi 48 jam, proses fermentasi pakan penelitian dihentikan dengan ditetesi larutan $\mathrm{HgCl}$ jenuh sebanyak 2 tetes, disentrifugasi dengan kecepatan $3500 \mathrm{rpm}$ selama 15 menit untuk memisahkan endapan pakan dan supernatannya. Endapan pakan digunakan untuk mengukur kecernaan Bahan Kering (KcBK) dan kecernaan Bahan Organik (KcBO). Sementara itu supernatannya digunakan untuk penetuan konsentrasi ammonia.

Penentuan $\mathrm{KcBK}$ dan $\mathrm{KcBO}$ dilakukan dengan menganalisis kandungan bahan kering dan bahan organik residu sampel setelah 48 jam inkubasi. KcBK dan $\mathrm{KcBO}$ dihitung dengan formula sebagai berikut:

$$
\begin{gathered}
K c B K=\frac{\text { berat } B K \text { sampel },(\mathrm{g})-(\text { berat } B K \text { residu, }(\mathrm{g})-\text { berat } \mathrm{BK} \text { blanko, }(\mathrm{g})}{\text { berat } \mathrm{BK} \text { sampel }(\mathrm{g})} \times 100 \% \\
K c B O=\frac{\text { berat } \mathrm{BO} \text { sampel },(\mathrm{g})-(\text { berat } \mathrm{BO} \text { residu, }(\mathrm{g})-\text { berat } \mathrm{BO} \text { blanko, }(\mathrm{g})}{\text { berat } \mathrm{B} 0 \text { sampel }(\mathrm{g})} \times 100 \%
\end{gathered}
$$

\section{Pengukuran Produksi Amonia $\left(\mathrm{NH}_{3}\right)$}

Pengukuran produksi $\mathrm{NH}_{3}$ menggunakan metode Mikrodifusi conway (General Laboratory Procedure, 1966). Sebelum digunakan, bibir cawan conway diolesi dengan vaselin. Sebanyak $1 \mathrm{ml}$ supernatan diambil kemudian dimasukan pada salah satu sisi alur dari cawan conway. Sedangkan sisi yang lain diisi dengan $1 \mathrm{ml}$ $\mathrm{Na}_{2} \mathrm{CO}_{3}$ jenuh. Antara supernatan dan $\mathrm{Na}_{2} \mathrm{CO}_{3}$ tidak boleh bercampur. Larutan asam borat berindikator sebanyak $1 \mathrm{ml}$ ditempatkan dalam cawan kecil yang terletak di tengah cawan conway, kemudian cawan conway langsung ditutup rapat hingga kedap udara. Kemudian cawan conway digoyang-goyangkan hingga supernatan dan $\mathrm{NaCO}_{3}$ tercampur rata, disimpan pada suhu kamar selama 24 jam. Setelah 24 jam asam borat berindikator dititrasi dengan $\mathrm{H}_{2} \mathrm{SO}_{4} 0,005 \mathrm{~N}$ sampai terjadi perubahan warna dari biru menjadi merah.

Produksi ammonia dihitung dengan menggunakan persamaan sebagai berikut:

$$
\mathrm{NH}_{3(\mathrm{mM})}=\frac{\text { Volume } \left.\mathrm{H}_{2} \mathrm{SO}_{4} \times \mathrm{N}_{2} \mathrm{H}_{2} \mathrm{SO}_{4}\right)}{\text { berat BK sampel (g) }} \times 1000
$$

\section{Analisis Statistik}

Penelitian dilaksanakan dalam Rancangan Acak Lengkap (RAL) yang terdiri dari 4 perlakuan dan 5 ulangan. Masing-masing ulangan berisi 2 unit percobaan dan 3 blanko. Analisis ragam (ANOVA) dilakukan untuk melihat efek perlakuan terhadap peubah yang diukur. Uji Duncan digunakan untuk mengidentifikasi perbedaan rataan dari setiap perlakuan, menggunakan tingkat kepercayaa $\mathrm{P}<0.05$. Untuk mengestimasi jumlah IZ yang digunakan sebagai suplemen protein dalam pakan dilihat dengan uji polynomial orthogonal menggunakan aplikasi exel. Sedangkan rataan standar error of mean (SEM) dihitung dari rerata kuadrat tengah galat. Analisis statistik menggunakan program SPSS versi 17. 


\section{HASIL DAN PEMBAHASAN \\ Produksi Gas dan Gas Metan}

Tabel 3. Efek suplementasi I. zolingeriana (IZ) dalam pakan terhadap produksi gas total, gas metan dan persentase gas metan di rumen

\begin{tabular}{lcccccc}
\hline Parameter & R0 & R1 & R2 & R3 & SEM & P \\
\hline Produksi Gas Tota1,m1 & $68.24^{\mathrm{d}}$ & $75.30^{\mathrm{c}}$ & $78.63^{\mathrm{b}}$ & $81.24^{\mathrm{a}}$ & 0.67 & $<0.001$ \\
Gas Metan, m1 & $33.07^{\mathrm{b}}$ & $36.00^{\mathrm{c}}$ & $34.02^{\mathrm{b}}$ & $31.25^{\mathrm{a}}$ & 0.49 & $<0.001$ \\
Gas Metan,\% & $48.47^{\mathrm{c}}$ & $47.80^{\mathrm{c}}$ & $43.28^{\mathrm{b}}$ & $38.48^{\mathrm{a}}$ & 0.67 & $<0.001$ \\
\hline
\end{tabular}

SEM: standard error of mean, P: probability

Superskrip a-d berbeda pada baris yang sama berbeda $(\mathrm{P}<0.05)$

Hasil pengukuran efek suplementasi $I$. zolingeriana dalam pakan terhadap produksi gas dan gas metan seperti tercantum pada Tabel 3. Pada Tabel 3 terlihat bahwa perlakuan suplementasi IZ sampai dengan taraf $30 \%(\mathrm{R} 3)$ nyata $(\mathrm{P}<0.05)$ berpengaruh terhadap produksi gas total, gas metan dan persentase gas metan. Produksi gas total meningkat $(\mathrm{P}<0.05)$ dengan semakin meningkatnya taraf suplementasi IZ dalam pakan. Peningkatan ini mengindikasikan bahwa suplementasi IZ mampu memperbaiki fermentabilitas dari pakan. Disamping itu, IZ memiliki kualitas yang lebih baik dibandingkan pakan dasar (R0, Tabel 1). Namun demikian terlihat bahwa produksi gas metan dan persentase gas metan mengalami penurunan dengan meningkatnya taraf suplementasi IZ dalam pakan,
Persentase gas metan mengalami penurunan sebesar 0.67, 5.19 dan $9.99 \%$ masing-masing untuk perlakuan R1, R2 dan R3, dibandingkan dengan R0 (kontrol). Penurunan persentase gas metan yang diperoleh dalam penelitian ini relatif rendah dibandingkan dengan yang dilaporkan Denek dkk. (2017), dimana suplementasi pistachio by product yang mengandung $8 \%$ tannin kondensasi mampu menurunkan produksi metan $30 \%$. Rendahnya penurunan persentase gas metan yang diperoleh dalam penelitian ini disebabkan karena rendahnya kandungan tannin pada IZ yakni sekitar 0.090.65\% (Abdullah, 2010). Lebih lanjut Hariadi dan Santoso (2010) melaporkan bahwa produksi metan akan menurun dengan semakin meningkatnya kandungan tannin pada tanaman.

\section{Kecernaan Pakan dan Produk Metabolik Rumen}

Kecernaan pakan yang diukur dalam penelitian ini meliputi nilai Kecernaan Bahan Kering (KcBK) dan Kecernaan Bahan Organik (KcBO). Sedangkan produk metabolik rumen yang diukur terdiri dari nilai $\mathrm{pH}$, konsentrasi ammonia $\left(\mathrm{N}-\mathrm{NH}_{3}\right)$ rumen, total volatile fatty acid (TVFA). energy metabolism (ME), dan produksi protein mikroba (PPM). Data hasil pengukuran kecernaan pakan dan produk metabolik rumen dapat dilihat pada Tabel 4.

Tabel 4. Efek suplementasi I. zollingeriana (IZ) dalam pakan terhadap KcBK, KcBO dan produk metabolik rumen

\begin{tabular}{lcccccc}
\hline Parameter & R0 & R1 & R2 & R3 & SEM & P \\
\hline KcBK, \% & $50.00^{\mathbf{b}}$ & $69.06^{\mathbf{a}}$ & $47.49^{\mathbf{b c}}$ & $43.95^{\mathbf{c}}$ & 1.60 & $<0.001$ \\
$\mathrm{KcBO}, \%$ & $54.39^{\mathbf{b}}$ & $73.89^{\mathbf{a}}$ & $53.46^{\mathbf{b}}$ & $53.85^{\mathbf{b}}$ & 1.18 & $<0.001$ \\
$\mathrm{pH}$ & $7.35^{\mathbf{a}}$ & $7.04^{\mathbf{b}}$ & $6.71^{\mathbf{c}}$ & $7.20^{\mathbf{a b}}$ & 0.07 & $<0.001$ \\
$\mathrm{~N}-\mathrm{NH}_{3}, \mathrm{mg} / \mathrm{dl}$ & $9.86^{\mathbf{a}}$ & $15.37^{\mathbf{b}}$ & $18.70^{\mathbf{b}}$ & $23.97^{\mathbf{c}}$ & 1.14 & $<0.001$ \\
$\mathrm{TVFA}, \mu \mathrm{mol} / \mathrm{l}$, & $0.98^{\mathbf{d}}$ & $1.24^{\mathbf{c}}$ & $1.32^{\mathbf{b}}$ & $1.42^{\mathbf{a}}$ & 0.02 & $<0.001$ \\
$\mathrm{ME}, \mathrm{MJ} / \mathrm{kg} \mathrm{BK}$ & $8.13^{\mathbf{d}}$ & $9.59^{\mathbf{c}}$ & $10.08^{\mathbf{b}}$ & $10.63^{\mathbf{a}}$ & 0.12 & $<0.001$ \\
$\mathrm{PPM}, \mathrm{mg} / \mathrm{g}$ & $154.13^{\mathbf{b}}$ & $225.83^{\mathbf{a}}$ & $110.09^{\mathbf{c}}$ & $83.53^{\mathbf{d}}$ & 7.46 & $<0.001$ \\
\hline
\end{tabular}

SEM: standard error of mean, P: probability, KcBK : Kecernaan bahan kering, KcBO: Kecernaan bahan organik, N-NH${ }_{3}$ Namonia, TVFA: Total volatile fatty acid, ME: Metabolisme energy, PPM: Produksi protein mikroba.

Superskrip a-d berbeda pada baris yang sama berbeda $(\mathrm{P}<0.05)$

Nilai KcBK dan KcBO (Tabel 4) yang diperoleh nyata $\mathrm{P}<0.05)$ dipengaruhi oleh taraf suplementasi IZ dalam pakan. Nilai KcBK dan KcBO tertinggi diperoleh pada taraf suplementasi IZ sebesar $10 \%$ (R1) nyata lebih tinggi dibandingkan perlakuan R0, R2 dan R3., peningkatan taraf suplementasi IZ di atas $10 \%$ cenderung menyebabkan penurunan nilai $\mathrm{KcBK}$ dan $\mathrm{KcBO}$. Hal ini terjadi diakibatkan oleh karena adanya peran metabolik sekunder yang terdapat pada IZ, terutama tannin. Semakin tinggi jumlah suplementasi IZ yang diberikan menyebabkan terjadinya peningkatan konsentrasi tannin. Besarnya pengaruh tannin terhadap $\mathrm{KcBK}$ dan $\mathrm{KcBO}$ merupakan suatu fungsi dari dosis, jenis tannin dan bobot molekul (Getachew dkk., 2008). Pada konsentrasi tinggi, tanin dapat mengurangi konsumsi ransum dikarenakan rasanya yang astringent serta menurunkan kecernaan (Mueller-Harvey 2006). Namun demikian, nilai KcBK dan KcBO yang diperoleh masih berada penilaian kualiatas pakan yang baik, sehingga suplementasi IZ sampai $30 \%$ (R3) belum mengganggu kecernaan zat makanan meski kandungan tanin yang diberikan meningkat. Hasil penelitian Cieslak dkk. (2016), dimana penggunaan ekstrak tannin dari Sanguisorba officinale (SOTE) sampai $40 \mathrm{mg}$ tidak menyebabkan efek negatif terhadap kecernaan. Sementara itu kadar tanin pada penelitian ini berkisar antara $0.3-1.95 \mathrm{~g} / \mathrm{kg}$. Tanin mempunyai efek biologis baik yang bersifat positif maupun negatif tergantung pada konsentrasi serta sumber, tergantung pada konsentrasi serta sumber tana-mannya (Makkar, 2003).

Pengukuran kondisi $\mathrm{pH}$ rumen penting dilakukan karena kondisi $\mathrm{pH}$ berperan penting dalam 
mempengaruhi aktifitas mikroba dalam proses pencernaan pakan. Nilai $\mathrm{pH}$ berada di bawah 6.2 berpengaruh negatif pada kecernaan fraksi serat, sementara nilai $\mathrm{pH}$ dibawah 5.5 akan berdampak terhadap kejadian rumen asidosis, menurunkan konsumsi dan bahkan pada kondisi ekstrim ternak tidak mau makan (off feed) serta dapat menyebabkan problem yang serius. Oleh karena itu penting untuk menjaga keseimbangan $\mathrm{pH}$ dan populasi mikroba rumen. Nilai $\mathrm{pH}$ dapat bervariasi sekitar 5.5-7.5 tergantung pada tipe pakan dan frekuensi pemberian pakan (Franzolin dan Dehority, 2010). Hasil pengukuran efek suplementasi IZ nyata $(\mathrm{P}<0.05)$ mempengaruhi nilai $\mathrm{pH}$ rumen. Nilai $\mathrm{pH}$ rumen yang diperoleh bervariasi antara 6.71-7.35. Nilai $\mathrm{pH}$ yang diperoleh masih berada batas $\mathrm{pH}$ yang ideal untuk aktifitas mikroba di rumen (Van Soest, 1994), dan di atas 6.0 yang dibutuhkan untuk sintesis protein mikroba (Russell dkk., 1992).. Jadi efek suplementasi IZ sampai dengan taraf 30\% (R3) tidak berdampak negatif pada kondisi $\mathrm{pH}$ rumen.

Pengukuran konsentrasi $\mathrm{N}-\mathrm{NH}_{3}$ penting dilakukan pada ternak ruminansia guna mengevaluasi kualitas pakan sumber protein yang diberikan. Semakin tinggi jumlah $\mathrm{N}-\mathrm{NH}_{3}$ yang terbentuk di rumen, menunjukkan bahwa semakin tingginya protein pakan yang didegradasi oleh mikroba rumen serta dapat digunakan sebagai indicator rendahnya efisiensi sumber protein. Hasil pengukuran efek taraf suplementasi IZ sebagai sumber protein, nyata $(\mathrm{P}<0.05)$ meningkatkan konsentrasi $\mathrm{N}-\mathrm{NH}_{3}$ (Tabel 4). Konsentrasi $\mathrm{N}-\mathrm{NH}_{3}$ yang diperoleh bervariasi 9.86-23.97 mg/dl. Nilai ini berada di atas ambang yang dibutuhkan oleh mikroba rumen. Menurut Satter dan Slyter (1974), konsentrasi N-NH sebesar $5 \mathrm{mg} / \mathrm{dl}$ sudah cukup untuk mendukung pertumbuhan mikroba yang optimal untuk membantu proses pencernaan pakan. Gambaran hubungan taraf suplementasi IZ dengan konsentrasi $\mathrm{N}-\mathrm{NH}_{3}$ tercantum pada Gambar 1.

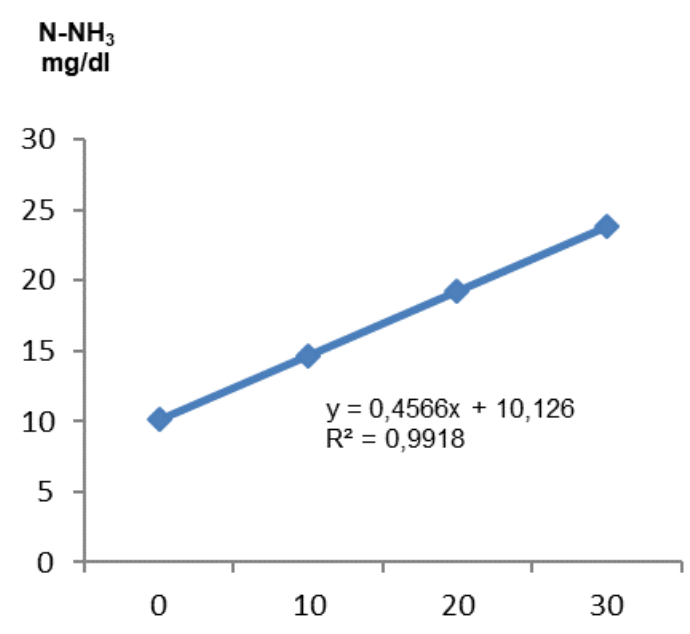

Taraf Suplementasi I. zolingeriana (\%)
Pada Gambar 1, terlihat bahwa semakin tinggi taraf suplementasi IZ konsentrasi $\mathrm{N}-\mathrm{NH}_{3}$ semakin meningkat. Kondisi ini menunjukkan bahwa kandungan protein dari IZ yang tinggi $(28.12 \%)$ berperan dalam meningkatkan konsentrasi $\mathrm{N}^{-\mathrm{NH}_{3}}$. Tingginya konsentrasi $\mathrm{N}^{-\mathrm{NH}_{3}}$ menunjukkan bahwa IZ sebagai sumber protein, memiliki sifat ketahan protein yang rendah terhadap degradasi oleh mikroba rumen. Pada gambar 1 di atas terlihat bahwa peningkatan taraf suplementasi IZ akan akan meningkatkan konsentrasi N$\mathrm{NH}_{3}$ sebesar $0,4566 \mathrm{mg} / \mathrm{dl} \quad(45.66 \%)$ untuk setiap peningkatan taraf suplementasi IZ. Peningkatan ini disebabkan karena mikroba rumen cenderung untuk merombak protein menjadi ammonia, selanjutnya ammonia akan digunakan untuk produksi masa sel mikroba. Namun demikian tidak semua $\mathrm{N}-\mathrm{NH}_{3}$ yang terbentuk digunakan oleh mikroba, sebagian akan di ekskresikan melalui urin dan feses yang berkontribusi sebagai polutan pada air, emisi gas $\mathrm{N}$ serta sejumlah kecil partikel yang terbentuk di atmosfer (Kulling dkk., 2003; Hristov, 2011; Hristov dkk., 2011; Cameron dkk., 2013). Bahan pakan sumber protein yang bersifat seperti di atas, meskipun memiliki kandungan protein yang tinggi, namun tidak dapat digolongkan pada sumber protein yang berkualitas untuk ternak ruminansia. Ketika protein pakan perombakannya berlebihan, akibatnya efisiensi pemanfaatannya untuk produksi menurun tajam dan sejumlah besar hilang sebagai $\mathrm{N}$-feses, urin, dan gas $\mathrm{N}$ yang dapat menyebabkan efek negatif terhadap lingkungan. Disamping itu menyebabkan meningkatnya biaya dan efisiensi protein yang rendah (Bach dkk., 2005; Ružić-Muslić, 2014).

Efek peningkatan taraf suplementasi IZ nyata $(\mathrm{P}<0.05)$ meningkatkan TVFA dan ME (Tabel 4). Hal ini menunjukkan bahwa IZ memiliki nilai fermentabilitas yang lebih baik. Produksi TVFA berkorelasi positif dengan nilai ME. Hal ini disebabkan karena TVFA berkontribusi sebesar $65-75 \%$ terhadap ME yang dihasilkan (Penner dkk., 2009). Produksi gas fermentasi secara kualitatif dan kuantitatif merupakan hasil dari produksi TVFA. Hasil ini semakin jelas mengkonfirmasi keberadaan tannin pada IZ tidak menyebabkan efek negatif terhadap fermentabilitas, bahkan memperlihatkan sumbangannya yang besar terhadap ketersedia energy pada ternak ruminansia.

Protein mikroba rumen merupakan sumber utama asam amino dan berkontribusi sekitar dua pertiga dari asam amino yang diabsorbsi oleh ternak ruminansia (Pathak, 2008). Hasil pengukuran efek taraf suplementasi IZ sebagai sumber protein nyata $(\mathrm{P}<0.05)$ berpengaruh terhadap produksi protein mikroba (PPM) (Tabel 4). Hubungan taraf suplementasi IZ terhadap produksi protein mikroba seperti tercantum pada Gambar 2.

Gambar 1. Hubungan taraf suplementasi I. zolingeriana terhadap $\mathrm{N}-\mathrm{NH}_{3}$ 


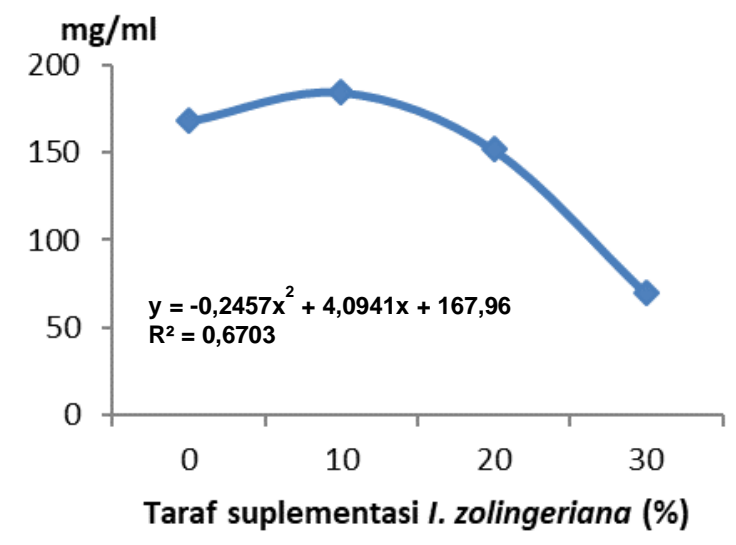

Gambar 2. Hubungan taraf suplementasi I. zolingeriana terhadap produksi protein mikroba

Pada Gambar 2 di atas, terlihat bahwa produksi protein mikroba optimal terjadi pada suplementasi IZ taraf $10 \%$ (R1). Hal ini erat kaitannya dengan jumlah bahan organik yang dicerna. Dimana pada taraf suplementasi IZ sebesar 10\%, jumlah bahan organik yang dicerna sebesar $73.89 \%$ lebih tinggi dibandingkan dengan perlakuan R0, R2 dan R3 masing-masing sebesar 54.39, 53.46 dan 53.85\%. Pathak (2008), menyatakan terdapat hubungan yang erat antara bahan organik (BO) yang dicerna dengan sintesis protein mikroba, dimana efisiensi sintesis protein mikroba meningkat dengan meningkatnya ketersediaan bahan organik yang dicerna. Meskipun suplementasi IZ menyebabkan peningkatan secara linier konsentrasi $\mathrm{N}-\mathrm{NH}_{3}$, namun tidak linier menyebabkan peningkatan sintesis protein mikroba akibat tidak cukup disuplai dari BO yang dicernaan. Hal ini memperkuat asumsi bahwa kelebihan produksi $\mathrm{N}$ $\mathrm{NH}_{3}$ tidak memberikan manfaat yang positif untuk produksi protein mikroba, bahkan justru dapat menurunkan nilai efisiensi protein karena nitrogen akan banyak diekskresikan melalui urin dan feses. Fungsi utama metabolism karbohidrat oleh mikroba rumen adalah untuk menghasilkan energy bebas dalam bentuk ATP yang dibutuhkan untuk pertumbuhan mikroba. Pola dan tingkat metabolism nitrogen untuk sintesis protein mikroba sangat tergantung pada ketersediaan energi yang dihasilkan oleh fermentasi karbohidrat. Rata-rata, 20 gram protein bakteri disintesis per 100 gram bahan organik yang difermentasi dalam rumen (Harun dan Sali 2019).

\section{SIMPULAN}

Suplementasi I. zolingeriana (IZ) mampu menurunkan produksi gas metan dan persentase gas metan. Karakteristik protein dari IZ tidak tahan terhadap perombakan oleh mikroba rumen yang ditandai dengan peningkatan konsentrasi $\mathrm{N}^{-\mathrm{NH}_{3}}$ sebesar $45.66 \%$ untuk setiap peningkatan taraf suplementasi. Produksi protein mikroba optimal diperoleh pada taraf suplementasi IZ $10 \%$ (R1) yakni sebesar $184.33 \mathrm{mg} / \mathrm{ml}$. Perlu upaya proteksi protein dilakukan, jika IZ sebagai bahan pakan sumber protein hijau akan digunakan dalam pakan ternak ruminansia.

\section{DAFTAR PUSTAKA}

Abdullah, L. 2014. Prospektif agronomi dan ekofisiologi indigofera zollingeriana sebagai tanaman penghasil hijauan pakan berkualitas tinggi. Pastura. 3 (2) : $79-83$.

Abdullah, L., 2010. Herbage production and quality of shrub Indigofera treated by different concentration of foliar fertiliser. Med. Pet. 33 (3): 169-175.

Bach, A., S. Calsamiglia, and M. D. Stern. 2005. Nitrogen Metabolism in the Rumen. J. J. Dairy Sci. 88:(E. Suppl.):E9-E21.

Bioscreen Technologies. 2015. Bioscreen technologies research laboratories - artificial rumen by-pass analysis of rumen protected feed additives. https://www.youtube.com/watch?v=AAT63sytI0 w.

Broderick, G.A. 2017. Optimizing ruminant conversion of feed protein to human food protein. Animal, 12 (8): 1722-1734

Cameron, K. C., H. J. Di, and J. L. Moir. 2013. Nitrogen losses from the soil/plant system: A review. Ann. Appl. Biol. 162:145-173.

Cieslak, A., P. Zmora, A. Matkowski, I. Nawrot-Hadzik, E. Pers-Kamczyc, M. El-Sherbiny1, M. Bryszak1 and M. Szumacher-Strabel. (2016). Tannins from Sanguisorba officinalis affect in vitro rumen Methane production and fermentation. The J. of Anim. \& Plant Sci. 26(1): 54-62.

Denek, N., S.S. Aydin, A. Can. 2017. The effects of dried pistachio (Pistachio vera L.) by-product addition on corn silage fermentation and in vitro methane production. J Appl Anim Res. 45:185189.

Fievez. V., O.J. Babayemi and D. Demeyer, D. 2005. Estimation of direct and indirect gas production in syringe: a tool estimate short chain fatty acid production the requires minimal laboratory facilities. Animal Feed Science and Technology. 5(1):197-210.

Franzolin, R., dan B.A. Dehority. 2010. The role of $\mathrm{pH}$ on the survival of rumen protozoa in steers. $\mathrm{R}$. Bras. Zootec., 39 (10): 2262-2267.

General Laboratory Procedure. 1966. Report of Dairy Science. University of Wisconsin Madison.USA.

Getachew G., W. Pittroff, D.H. Putnam, A. Dandekar, S. Goyal, EJ. DePeters. 2008. The influence of addition of gallic acid, tannic acid or quebracho tannins to alfalfa hay on in vitro rumen fermentation and microbial protein synthesis. Anim Feed Sci Technol. 140:444-461.

Hariadi, B.T. and Santoso, B. 2010. Evaluation of tropical plants containing tannin on in vitro methanogenesis and fermentation parameters 
using rumen fluid. J. Sci. Food and Agric. 90 (3): 456-461.

Harun, A.Y. dan K. Sali. 2019. Factors affecting rumen microbial protein synthesis: A review. Vet Med Open J. 4(1): 27-35.

Hristov, A. N. 2011. Contribution of ammonia emitted from livestock to atmospheric PM2.5 in the United States. J. Dairy Sci. 94:3130-3136.

Hristov, A. N., M. Hanigan, A. Cole, R. Todd, T. A. McAllister, P. M. Ndegwa, and A. Rotz. 2011. Ammonia emissions from dairy farms and beef feedlots: A review. Can. J. Anim. Sci. 91:1-35.

Kulling, D. R., H. Menzi, T. F. Krober, A. Neftel, F. Sutter, P. Lischer, and M. Kreuzer. 2003. Ammonia, nitrous oxide and methane emissions from differently stored dairy manure derived from grass- and hay-based rations. Nutrient Cycling in Agro-ecosystems 65: 13-22,

Kumalasari, N.R., G. P. Wicaksono, \& L. Abdullah. 2017. Plant growth pattern, forage yield, and quality of Indigofera zollingeriana influenced by row spacing. Media Peternakan. 40(1):14-19.

Makkar, H.P.S. 2003. Effects and fate of tannins RužićMuslić, D., M.P. Petrović, M.M. Petrović, Z. Bijelić, V. Caro-Petrović, N. Maksimović, V. Mandić. 2014. Protein source in diets for ruminant nutrition. J. Biotechnology in Animal Husbandry 30 (2), p 175-184.

Menke, K.H., Steingass, H., 1988. Estimation of the energetic feed value obtained from chemical analysis and gas production using rumen fluid. Anim. Res. Dev. 28, 7-55.

Mueller-Harvey, I., 2006. Unravelling the conundrum of tannins in animal nutrition and health. Journal of the Science of Food and Agriculture 86, 20102037.

Pathak, A.K. 2008. Various factors affecting microbial protein synthesis in the rumen. Review. Veterinary World, Vol.1(6): 186- 189

Penner G.B., J.R. Aschenbach, G. Gäbel, R. Rackwitz, and M.Oba. 2009. Epithelial capacity for apical uptake of short chain fatty acids is a key determinant for intraruminal $\mathrm{pH}$ and the susceptibility to subacute ruminal acidosis in sheep. J. Nutr. 139 (9), 1714-1720.

Russell J.B., J.D. O'Connor, D.G. Fox, P.J. Van Soest and C.J. Sniffen, 1992. A net carbohydrate and protein system for evaluating cattle diets. I. Ruminal fermentation. J Anim Sci 70:3551-3561.

Ružić-Muslić, D., M.P. Petrović, M.M. Petrović, Z. Bijelić, V. Caro-Petrović, N. Maksimović, V. Mandić. 2014. Protein source in diets for ruminant nutrition. J. Biotechnology in Animal Husbandry 30 (2), p 175-184.

Satter, L.D. dan L. L. Slyter. 1974. Effect of ammonia concentration on rumen microbial protein production in vitro. Brit. J. Nutr. 32:199-208.
Tilley, J.M.A. and R..A. Terry. 1963. A two-stage technique for the in vitro digestion of forage crops. Grass Forage Sci. 18:104-111.

Van Soest, P.J.1994. Nutritional Ecology of the Rumen $\left(2^{\text {nd }} E d\right)$. Comstock Publishing Associates, Ithaca, NY.p 476. 